\title{
Cytotoxic Activities of (Graptophyllum pictum (L.) Griff) Ethanolic Extract and Its Fractions on Human Colon Cancer Cell WiDr
}

\author{
Azizah Amin1, Andayana Puspitasari Gani², Retno Murwanti ${ }^{3 *}$ \\ ${ }^{1}$ Faculty of Pharmacy, Universitas Gadjah Mada, Yogyakarta, Indonesia \\ ${ }^{2}$ Department of Pharmaceutical Biology, Faculty of Pharmacy, Universitas Gadjah Mada, Yogyakarta, Indonesia \\ ${ }^{3}$ Department of Pharmacology and Clinical Pharmacy, Faculty of Pharmacy, Universitas Gadjah Mada, \\ Yogyakarta, Indonesia
}

\begin{abstract}
Colon cancer is the third most common cancer in the world. Treatments for colon cancer might cause major side effects, hence increase opportunities for the development of new cancer drugs. One of the plants that potential to develop as an anticancer agent is daun ungu (Graptophyllum pictum (L.) Griff). From previous studies, G.pictum had cytotoxic activity against several cancerous cell lines. Traditionally, G.pictum leaves have been used for hemorrhoid treatment. The purpose of this study was to determine the cytotoxic activity of G.pictum ethanolic extract and its fractions on human colon cancer WiDr cells and to elucidate the compounds contained in most active extracts/fractions. G.pictum was extracted using 70\% ethanol and fractionated using n-hexane, chloroform, and ethyl acetate, respectively. The yield of the extract obtained was $18.9 \%$. The yield of hexane, chloroform, ethyl acetate, and ethanol-water fractions were $1.07 \%, 2.93 \%$, $10.26 \%$, and $84.82 \%$, respectively. The cytotoxic activity was carried out on WiDr cells using the MTT assay. Cytotoxic activity was determined based on IC50 values. IC50 value of extract, hexane, chloroform, ethyl acetate and ethanol-water fraction obtained on WiDr cells were 1527,$58 ; 143,97 ; 507,19 ; 3538,67$ and $3186,60 \mu \mathrm{g} / \mathrm{mL}$. The hexane fraction containing terpenoids and phenolics showed the highest cytotoxic activities against WiDr colon cancer cells.
\end{abstract}

Keywords: G.pictum; colon cancer; cytotoxic; WiDr; CT-26

\section{INTRODUCTION}

Cancer is one of the major causes of death worldwide. In 2012, around 8.2 million deaths were caused by cancer. Colon cancer was thirdlargest cancer in the world, with more than 1.3 million new cases occurring every year. Nearly $55 \%$ of cases of colon cancer occur more in developing countries (American Cancer Society, 2017 and Ferlay et al., 2015).

One of the treatments for colon cancer is by giving chemotherapy. The use of chemotherapy can cause various kinds of side effects because it is not specific. The caused side effects can reduce the quality of life, which leads to complications of the disease (American Cancer Society, 2016 and Araújo et al., 2011). The development of new cancer drugs is needed to get drugs that are more potent, selective, and have lower side effects. Research for the development of anticancer drugs can be carried out by exploring natural compounds present in plants (Mehta et al., 2010)

One of the plants that have the potential as an anticancer agent is Graptophyllum pictum (L.) Griff or commonly known as daun ungu. Daun ungu is a plant from Indonesia and is traditionally used to treat hemorrhoids. Various biological activities

\footnotetext{
*Corresponding author : Retno Murwanti
}

Email : retno_murwanti@ugm.ac.id have been found from these plant extracts including anti-inflammatory, antioxidant and cytotoxic against line cells of lung cancer, oral cancer and breast cancer (Ozaki et al., 1989, Jiangseubchatveera et al., 2015 and 2017).

In this study, the cytotoxicity of the extract and fractions of daun ungu was carried out on WiDr's colon cancer cells. This study also identified the chemical content of daun ungu extract and its fractions, and to elucidate the active compounds that might play a role in its cytotoxicity.

\section{METHODOLOGY Materials}

Dried leaves of Graptophyllum pictum were collected from B2P2T00T Tawangmangu (Karanganyar, Jawa Tengah, Indonesia), 3-(4,5dimetilthiazol2-il)-2,5-difeniltetrazolium bromide (MTT) was purchased from Invitrogen, Roswell Park Memorial Institute (RPMI) medium, fetal bovine serum, and dimethyl sulfoxide (DMSO) were purchased from Gibco.

\section{Methods}

\section{Preparation of extract and fractions}

The dried powdered leaves of G.pictum (800 g) were macerated with $70 \%$ ethanol. The extract was filtered and concentrated using a 


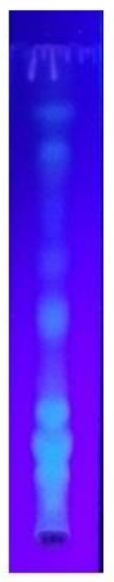

A

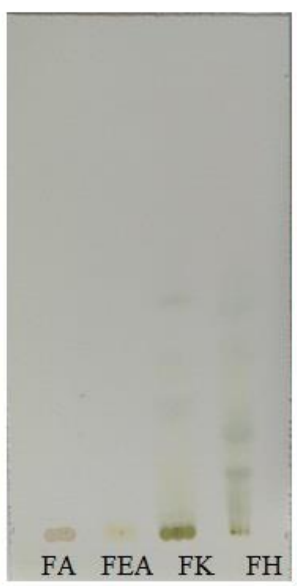

B

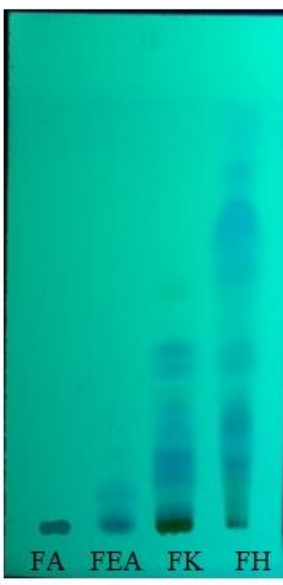

$\mathrm{C}$

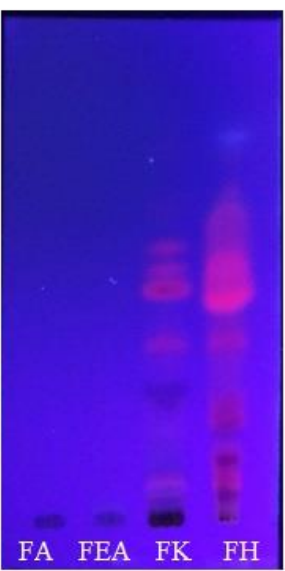

$\mathrm{D}$

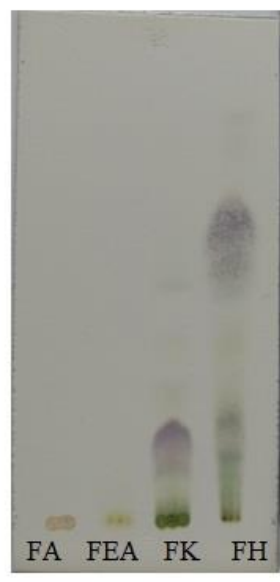

E

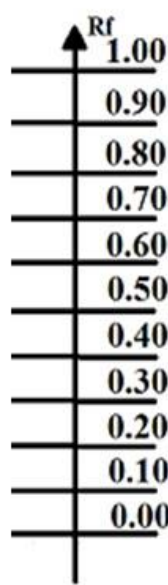

Figure 1. TLC profile of extract and fractions below UV 366. (A) TLC profile of extract with the stationary phase of silica gel F254 and mobile phase of ethyl acetate-glacial acetic acid (100:11:20 v/v) after sprayed with cytoborate reagent. (B) TLC profile of fractions with n-hexane-ethyl acetate mobile phase (4:1 v/v) visible light, (C) UV254, (D) UV366 and (E) after sprayed with anisaldehyd-sulfuric acid. Description: E: ethanolic extract, FH: n-hexane fraction, FK: chloroform fraction, FEA: ethyl acetate fraction and FA: ethanol-water fraction.

rotary evaporator (AISET XMTE3000). The extract then was partitioned with n-hexane, chloroform, and ethyl acetate continuously. Each fraction and the residue were concentrated and kept in desiccators.

\section{Identification of chemical content}

The extract was analyzed for TLC using the mobile phase ethyl acetate: P-glacial acetic acid: P-water (100:11:20) with the stationary phase of Silica gel $60 \mathrm{~F}_{254}$. The sample was eluted in the chamber. After that, the silica plate was dried and sprayed with sitoborat reagent and then heated at $110^{\circ}$ for 5-10 minutes and observed under UV254 and UV366.

Characterization of fractions was carried out using hexane-ethyl acetate $(4: 1 \mathrm{v} / \mathrm{v})$ and the stationary phase was Silica gel $60 \mathrm{~F}_{254}$. After the samples were eluted in the chamber, then it dried and observed under visible light, UV 254 and UV 366. The most active extract or fraction then were identified using various spray reagents.

\section{Cell culture}

WiDr human colon cancer cell line was obtained from the Faculty of Medicine, Universitas Gadjah Mada, Yogyakarta. WiDr cells were maintained in the medium consisting of Roswell Park Memorial Institute medium (RPMI) supplemented with $10 \%$ fetal bovine serum, $1,5 \%$ penicillin-streptomycin, $1 \% \mathrm{~L}$-glutamine at $37^{\circ} \mathrm{C}$ in $5 \% \mathrm{CO}_{2}$ incubator.

\section{Cytotoxicity assay}

WiDr cells were grown in the 96-well plate at a density of $1 \times 10^{4}$ cells per well. After $24 \mathrm{~h}$, cells were treated with various concentrations of extracts and fractions. After $24 \mathrm{~h}$ of treatments, cells were washed with Phosphate Buffer Solution (PBS) then $100 \mu \mathrm{L}$ of MTT $(0,5 \mathrm{mg} / \mathrm{mL}$ in medium) was added to each well. Four hours later, the reaction was stopped by $100 \mu \mathrm{L}$ of $10 \%$ (w/v) sodium dodecyl sulfonate in $0,01 \mathrm{~N} \mathrm{HCl}$ and incubated overnight. Cells viability was determined by measuring the absorbance at 595 $n m$ using ELISA reader (Bio-rad).

\section{RESULTS AND DISCUSSION}

The yield of ethanolic extract was 18.9\%, and the yield of n-hexane, chloroform, ethyl acetate, and ethanol-water fraction were $1,07 \%$, $2,93 \%, 10,26 \%$, and $84,82 \%$.

The TLC profile of extract (Figure $1 \mathrm{~A}$ ) using ethyl acetate-glacial acetic acid (100: 11: $20 \mathrm{v} / \mathrm{v}$ ) mobile phase showed intense blue and green spots after sprayed with cytoborate reagent (UV 366). According to Mabry et al., (1970), blue or green fluorescence spots indicate a flavonoid group. Based on the chromatogram profile (Figure $1 \mathrm{~B}, \mathrm{C}$, and D), the separation that occurs during the fractionation process is quite well indicated by the difference of each chromatogram profile of fractions.

The parameters of cytotoxic activity are $\mathrm{IC}_{50}$ values obtained from linear regression equations 

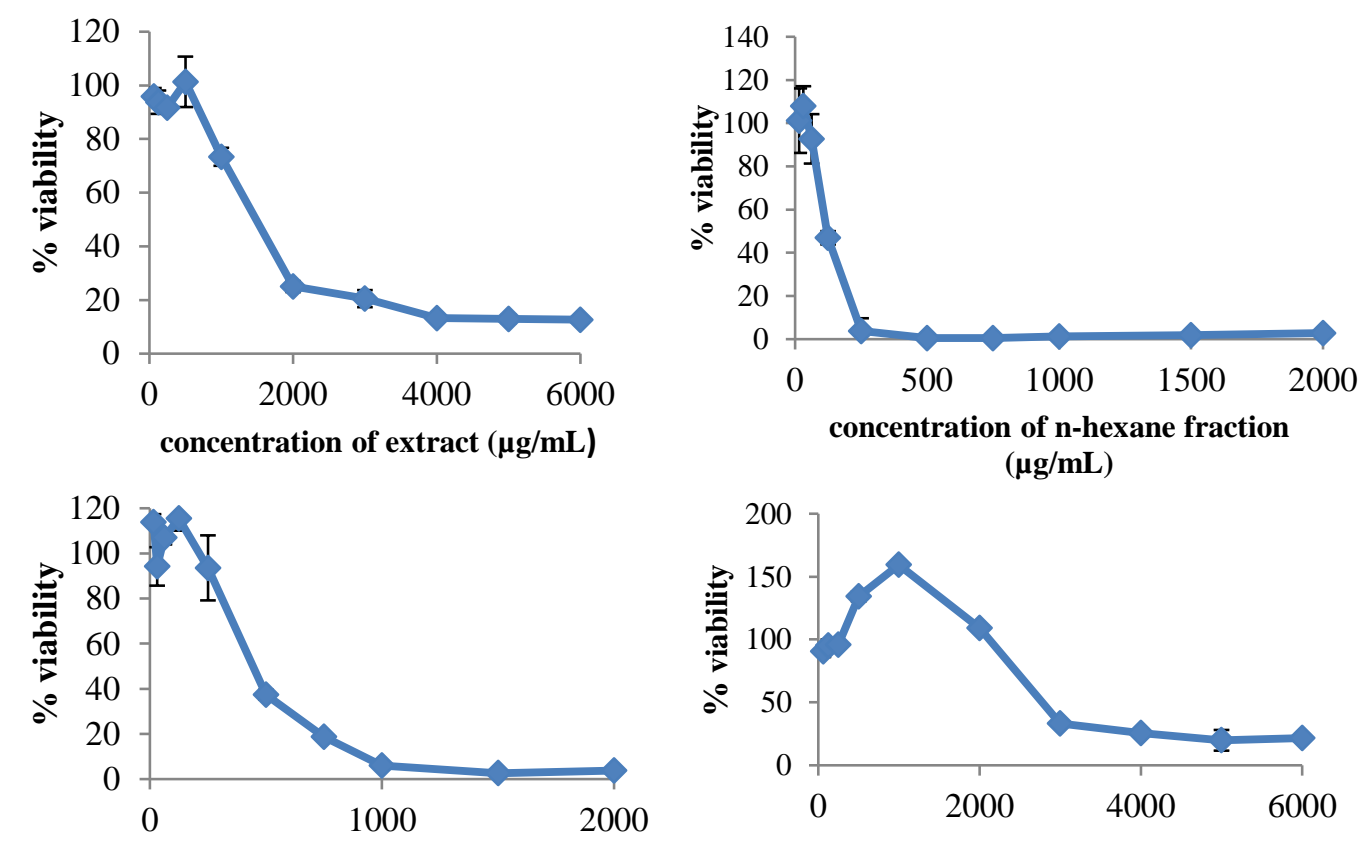

concentration of chloroform fraction $(\mu \mathrm{g} / \mathrm{mL})$

concentration of ethyl acetate fraction $(\mu \mathrm{g} / \mathrm{mL})$

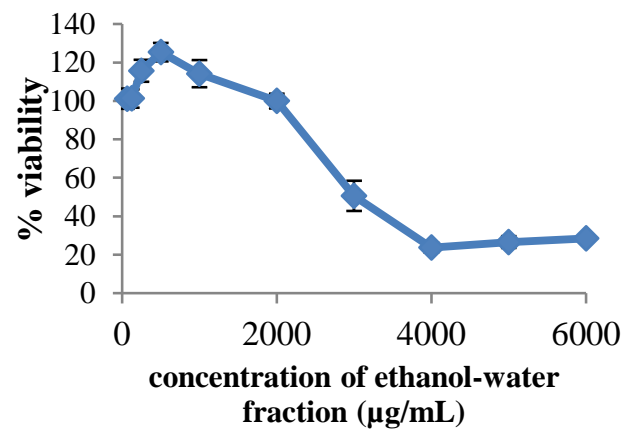

Figure 2. The effect of G.pictum ethanolic extract administration and n-hexane, chloroform, ethyl acetate, ethanol-water fraction on the viability of WiDr cells for 24 hours.
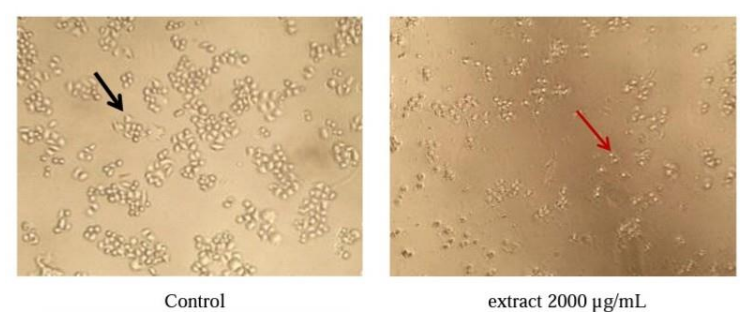

extract $2000 \mu \mathrm{g} / \mathrm{mL}$

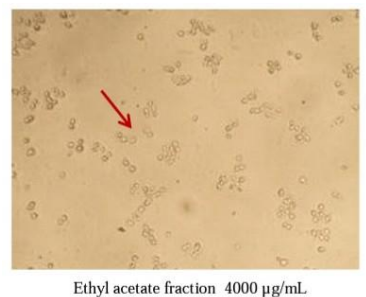

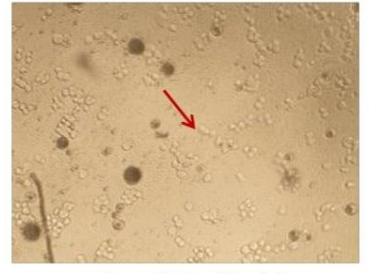

n-hexane fraction $125 \mathrm{\mu g} / \mathrm{mL}$

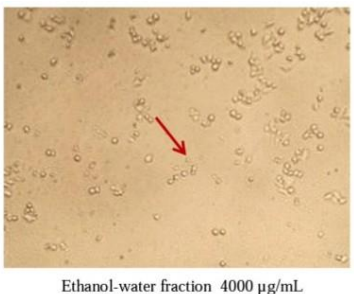

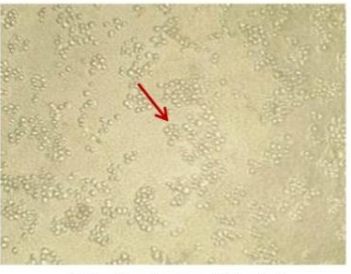

Chloroform fraction $500 \mu \mathrm{g} / \mathrm{mL}$

Figure 3. Morphology of cell after treatments. Observations were made with an inverted microscope magnification 200x. Black arrows indicate that living cells and red arrows indicate cells that have morphological changes. 


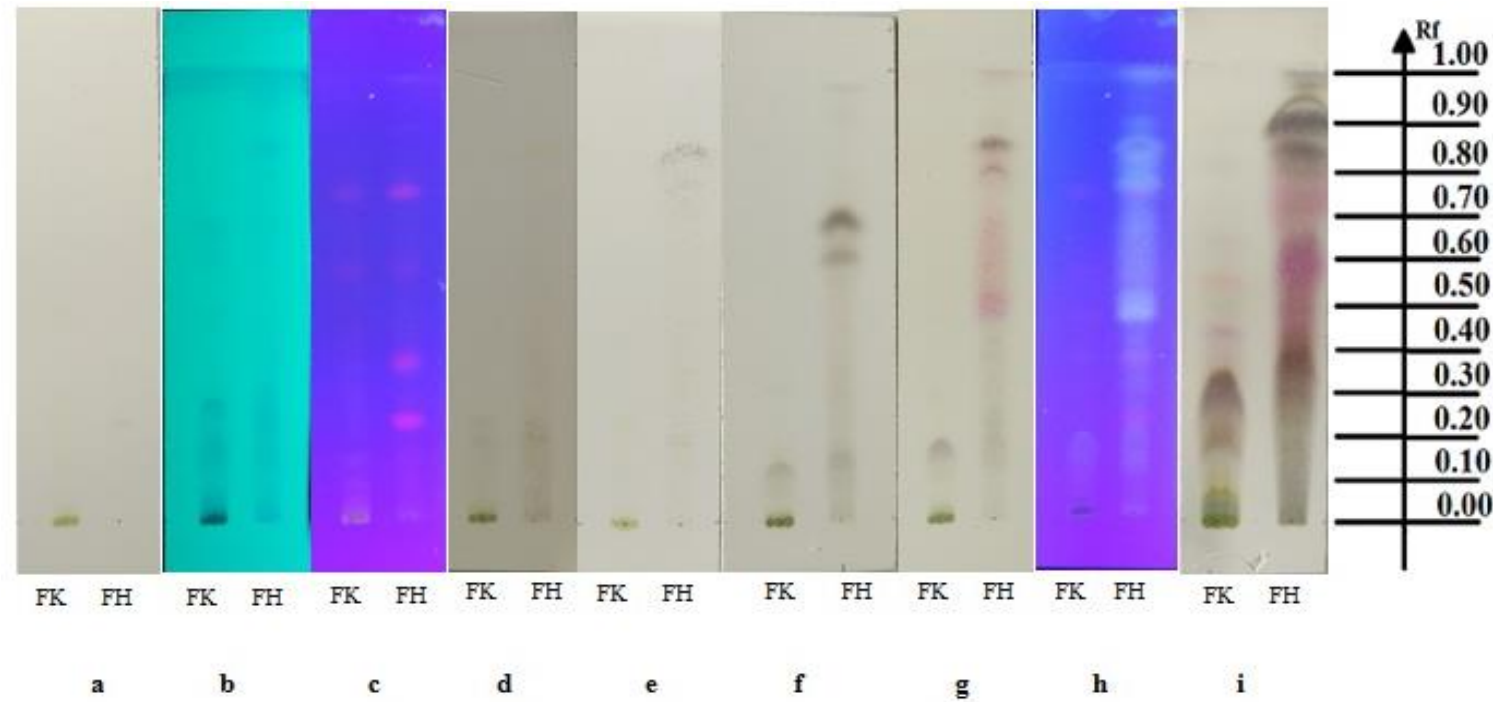

Figure 4. The results of TLC identification of n-hexane and chloroform fractions using various types of spray reagents.

Elution was carried out on silica gel F254, and the mobile phase was n-hexane-ethyl acetate (4:1 v/v). Observation of spots on visible light(a), observation of spots under UV254(b), under UV 366(c), after spraying $\mathrm{FeCl}_{3}(\mathrm{~d})$, after spraying $\mathrm{H}_{2} \mathrm{SO}_{4}(\mathrm{e})$, after spraying $\mathrm{LB}(\mathrm{f})$, after anisaldehyde sprayed on visible light(g), after being sprayed with anisaldehyde under UV 366(h) and after spraying with vanillin sulfuric acid(i). Description: FH: n-hexane fraction, FK: chloroform fraction

Table I. IC 50 values of G.pictum on WiDr cell

\begin{tabular}{cc}
\hline Sampel & IC 5 value $(\boldsymbol{\mu g} / \mathbf{m L})$ \\
\hline Ekstrak (EGP) & 2431,47 \\
Fraksi heksan (FHGP) & 195,61 \\
Fraksi kloroform (FKGP) & 507,20 \\
Fraksi etil asetat (FEAGP) & 3538,67 \\
Fraksi etanol-air (FAGP) & 3186,60 \\
\hline
\end{tabular}

between concentrations versus percent of cell viability. $\mathrm{IC}_{50}$ is a concentration that inhibits $50 \%$ cell growth. Cytotoxic assay was started from growing cells on a 96-microwell plate and incubating for 24 hours. After 24 hours of incubation, several series of concentrations from extract or fractions were treated for 24 hours. This incubation process aimed to make the extract, or fractions interact with cells and affect cell viability. The effect of extract or fractions on cells was observed through changes in cell morphology from observations using an inverted microscope.

Based on a linear regression equation from $\%$ viability vs. concentration (Figure 3 ), the IC50 values showed in Table I. Hexane fraction showed the most active cytotoxic activity against WiDr cells followed by chloroform fraction, ethanolic extract, ethanol-water fraction, and ethyl acetate fraction. G.pictum cytotoxic activity can also be seen based on cell morphology microscopically (Figure 4). WiDr cells without treatment (cell control) have a slightly oval round shape with a visible boundary between cells, forming colonies and attached on the well. The treated cells have morphological changes by having an irregular shape, smaller size, and with unclear inter-cell boundaries when compared to cell control.

The results of TLC identification with various spray reagents to the 2 most active fractions, n-hexane, and chloroform, showed that both of them contained terpenoids and phenolic compounds (Figure 5). Chloroform fraction also showed positive results for the three groups of compounds with a smaller color intensity compared to the hexane fraction so that the chloroform fraction had the second most active cytotoxic activity after the hexane fraction

One of the substances dissolved in hexane solvents is an essential oil. According to a study by (Jiangseubchatveera et al., 2015), the highest content of G.pictum essential oil was phytol. Phytol was reported to have cytotoxic activity against 
A549 cells (human lung carcinoma), induced the formation of apoptosis body and cause apoptosis mediated by ROS through activation of TRAIL, FAS and TNF- $\alpha$ receptor (Thakor et al., 2017). Maybe this phytol compound plays a role in the cytotoxic activity of G.pictum against cancer cells, but further research is needed.

\section{CONCLUSION}

In conclusion, ethanolic extracts of G.pictum and its fractions have cytotoxic activities against WiDr colon cancer cells. The hexane fraction showed the highest cytotoxic activities against WiDr colon cancer cells. It was found that the hexane fractions contained terpenoids and phenolics. The results suggest that these terpenoid and phenolics content may have a role in cytotoxic activities.

\section{ACKNOWLEDGMENT}

This study was supported by The Ministry of Research, Technology, and Higher education of the Republic of Indonesia through decentralization and national competitive research grant 2019 (2851/UN1.DITLIT/DIT-LIT/LT/2019).

\section{REFERENCES}

American Cancer Society, 2017. Colorectal Cancer Facts \& Figures 2017-2019. American Cancer Society, Atlanta.

American Cancer Society, 2016. Treating Colorectal Cancer. American Cancer Society, Atlanta.

Araújo, J.R., Gonçalves, P., Martel, F., 2011. 'Chemopreventive effect of dietary polyphenols in colorectal cancer cell lines'. Nutr. Res. 31, 77-87.

Ferlay, J., Soerjomataram, I., Dikshit, R., Eser, S., Mathers, C., Rebelo, M., Parkin, D.M., Forman, D., Bray, F., 2015. 'Cancer incidence and mortality worldwide: Sources, methods and major patterns in GLOBOCAN 2012'. Int. J. Cancer 136, 359-386.

Jiangseubchatveera, N., Liawruangrath, B., Liawruangrath, S., Teerawutgulrag, A., Santiarworn, D., Korth, J., Pyne, S.G., 2015. 'The Chemical Constituents and the Cytotoxicity, Antioxidant and Antibacterial Activities of the Essential Oil of Graptophyllum pictum (L.) Griff'. J. Essent. Oil Bear. Plants 18, 11-17.

Jiangseubchatveera, N., Liawruangrath, S., Teerawutgulrag, A., Santiarworn, D., Pyne, S.G., Liawruangrath, B., 2017. 'Phytochemical Screening, Phenolic and Flavonoid Contents, Antioxidant and Cytotoxic Activities of Graptophyllum pictum (L.) Griff'. Chiang Mai J Sci 44, 193202.

Mabry, T.J., Markham, K.R., Thomas, M.B., 1970. The Systematic Identification of Flavonoid. Springer-Verlag, Berlin.

Mehta, R.G., Murillo, G., Naithani, R., Peng, X., 2010. 'Cancer Chemoprevention by Natural Products: How Far Have We Come?' Pharm. Res. 27, 950-961.

Ozaki, Y., Setsuko Sekita, Soekeni Soedidgo, Masatoshi Harada, 1989. 'Antiinflammatory effect of Graptophyllum pictum (L.) Griff'. Chem. Pharm. Bull. 37, 2799-2802.

Thakor, P., Subramanian, R.B., Thakkar, S.S., Ray, A., Thakkar, V.R., 2017. 'Phytol induces ROS mediated apoptosis by induction of caspase 9 and 3 through activation of TRAIL, FAS and TNF receptors and inhibits tumor progression factor Glucose 6 phosphate dehydrogenase in lung carcinoma cell line (A549)'. Biomed. Pharmacother. 92, 491500 . 